Article

\title{
Treatment of Diethyl Phthalate Leached from Plastic Products in Municipal Solid Waste Using an Ozone-Based Advanced Oxidation Process
}

\author{
Sankaralingam Mohan ${ }^{1}$, Hadas Mamane ${ }^{2}$, Dror Avisar ${ }^{3} * \mathbb{D}$, Igal Gozlan ${ }^{3}$, Aviv Kaplan ${ }^{3}$ and \\ Gokul Dayalan ${ }^{1}$ (D) \\ 1 Environmental \& Water Resources Engineering, Department of Civil Engineering, Indian Institute of \\ Technology Madras, Chennai, Tamil Nadu 600036, India; smohan@iitm.ac.in (S.M.); \\ gkld93@gmail.com (G.D.) \\ 2 Environmental Engineering Program, School of Mechanical Engineering, Faculty of Engineering, \\ Tel Aviv University, Tel Aviv 69978, Israel; hadasmg@tauex.tau.ac.il \\ 3 School of Earth Sciences, The Water Research Center, Hydrochemistry, Tel Aviv University, Tel Aviv 69978, \\ Israel; gozlan.igal@gmail.com (I.G.); avivkaplan@tauex.tau.ac.il (A.K.) \\ * Correspondence: droravi@tauex.tau.ac.il
}

Received: 16 November 2019; Accepted: 6 December 2019; Published: 9 December 2019

\begin{abstract}
Plastic products in municipal solid waste result in the extraction of phthalates in leachate that also contains large amounts of organic matter, such as humic substances, ammonia, metals, chlorinated organics, phenolic compounds, and pesticide residues. Phthalate esters are endocrine disruptors, categorized as a priority pollutant by the US Environmental Protection Agency (USEPA). Biological processes are inefficient at degrading phthalates due to their stability and toxic characteristics. In this study, the peroxone (ozone/hydrogen peroxide) process $\left(\mathrm{O}_{3} / \mathrm{H}_{2} \mathrm{O}_{2}\right)$, an $\mathrm{O}_{3}$-based advanced oxidation process (AOP), was demonstrated for the removal of diethyl phthalate (DEP) in synthetic leachate simulating solid-waste leachate from an open dump. The impact of the $\mathrm{O}_{3}$ dose during DEP degradation; the formation of ozonation intermediate by-products; and the effects of $\mathrm{H}_{2} \mathrm{O}_{2}$ dose, $\mathrm{pH}$, and ultraviolet absorbance at $254 \mathrm{~nm}$ (UVC) were determined during ozonation. Removal of $99.9 \%$ of an initial $20 \mathrm{mg} / \mathrm{L}$ DEP was obtained via $120 \mathrm{~min}$ of ozonation (transferred $\mathrm{O}_{3}$ dose $=4971 \mathrm{mg} / \mathrm{L}$ ) with $40 \mathrm{mg} / \mathrm{L} \mathrm{H}_{2} \mathrm{O}_{2}$ in a semi-batch $\mathrm{O}_{3}$ system. Degradation mechanisms of DEP along with its intermediate products were also determined for the AOP treatment. Indirect $\mathrm{OH}$ radical exposure was determined by using a radical probe compound (pCBA) in the $\mathrm{O}_{3}$ treatment.
\end{abstract}

Keywords: advanced oxidation; diethyl phthalate (DEP); leachate; peroxone; solid waste; plastic; landfill

\section{Introduction}

Rapid urbanization and rising living standards have a major influence on the quantity and characteristics of municipal solid waste (MSW), further complicating the management and maintenance of sanitary landfills. Leachate is generated by the interaction of MSW with water that percolates through the landfill, producing highly polluted wastewater [1]. Many factors govern the quality and quantity of leachate, such as the composition of the waste, piling, seasonal variation, landfill technique, and structure of the landfill. In developed countries, possible options for leachate treatment include co-treatment with municipal wastewater and transportation to an ex situ treatment facility; however, even these treatment processes are not practiced nor affordable. Other advanced techniques include reverse osmosis and recirculation of the concentrated leachate back to the landfill to avoid groundwater contamination [2]. In many developing countries, open dumpsites serve as a final 
disposal point for the MSW; these are a burden for the environment as the leachate is not collected or treated. One of the major concerns in the generation of leachate, in terms of both quantity and quality, is groundwater contamination [1]. Leachate extracts multiple contaminants from MSW and creates complex interactions between hydrological and biogeochemical reactions. Leachate contains a large amount of organic matter consisting of humic substances, along with ammonia nitrogen, heavy metals, chlorinated organics, and phenolic compounds.

Phthalate esters, known as phthalates, are plasticizers that are used to increase the quality and durability of polymers [3]. Phthalates leach and migrate from the plastic products into the environment as they are bonded to the products by physical and not chemical means, posing serious environmental and human health problems [4]. Phthalates, considered priority pollutants, have broad applications worldwide; they have a high biological toxicity to humans and are considered endocrine disruptor compounds (EDC) by the US Environmental Protection Agency (USEPA), European Environmental Agency (EEA), and other environmental agencies [5]. Specifically, diethyl phthalate (DEP) is commonly found in leachate and groundwater due to its high solubility and wide use in many items, among them being cosmetics, paints, and toys [5]. The USEPA-issued national primary drinking water regulation regarding organic chemical contaminants for DEP is $0.006 \mathrm{mg} / \mathrm{L}$, which is the maximum permissible limit.

Studies have demonstrated the removal of organic contaminants and heavy metals from landfill leachate by various technologies, including pre-treatment techniques, such as a coagulation-flocculation process, stripping, and precipitation methods [6], followed by discharge to the municipal wastewater treatment plant, adsorption, or oxidation. Advanced oxidation processes (AOPs) have been successfully implemented for the degradation of recalcitrant substances from stabilized leachate (i.e., old leachate, which is less biodegradable) and to improve its biodegradation by increasing the ratio of biochemical to chemical oxygen demand ( $\left.\mathrm{BOD}_{5} / \mathrm{COD}\right)[7]$.

Ozone $\left(\mathrm{O}_{3}\right)$ alone and in combination with different processes has been shown to efficiently degrade bulk organic contaminants from wastewater [8]. Organic compounds in leachate can be oxidized by either a direct reaction with $\mathrm{O}_{3}$, or by $\mathrm{O}_{3}$ decomposition to form the non-selective hydroxyl $(\mathrm{OH})$ radicals at an alkaline $\mathrm{pH}$; alternative methods include the addition of an oxidant such as hydrogen peroxide $\left(\mathrm{H}_{2} \mathrm{O}_{2}\right)$ (termed peroxone process) or the addition of a catalyst at the natural water $\mathrm{pH}(7-8)$ [9]. For example, Amr et al. studied the removal of COD and color from a municipal landfill leachate using $\mathrm{O}_{3}$ combined with a zinc sulfate oxidation process and obtained $90 \%$ and $99 \%$ removal for COD and color, respectively, with a $1 \mathrm{~g} / 6 \mathrm{~g} \mathrm{ZnSO}$ dosage $\left(\mathrm{COD}_{0} / \mathrm{Zn}\right)$ at $180 \mathrm{~min}$ of treatment time [10]. In addition, Amr et al. compared and optimized COD and color removal for a stabilized landfill leachate using three different $\mathrm{AOP}$ systems: $\mathrm{O}_{3}$ alone, $\mathrm{O}_{3} /$ fenton, and $\mathrm{O}_{3} /$ persulfate [11]. The latter showed an improved performance efficiency compared to the other treatment processes for the removal of color, ammonia, and COD. Asaithambi et al. showed that the synergistic effect of a $\mathrm{O}_{3} /$ sonication/fenton-based AOP was more effective in treating leachate with minimal electrical energy for high removal efficiency of $100 \%$ color and $95 \%$ COD [4]. Several studies have shown the removal of DEP in water (not in leachate) using an AOP for the generation of $\mathrm{OH}$ radicals, such as ultraviolet radiation $(\mathrm{UV}) / \mathrm{TiO}_{2}$ [12], $\mathrm{O}_{3}[13]$ and $\mathrm{UV} / \mathrm{H}_{2} \mathrm{O}_{2}$ [5]. These studies demonstrated that $\mathrm{OH}$ radicals play a dominant role in AOP efficacy for DEP removal in water.

Due to the high percentage of plastics in MSW composition, there is a high concentration of phthalates in the leachate. However, the removal of phthalates by $\mathrm{O}_{3}$-based AOP from the complex matrix of MSW leachate has never been explored. In this study, an $\mathrm{O}_{3}$-based $\mathrm{AOP}$-the peroxone process $\left(\mathrm{O}_{3} / \mathrm{H}_{2} \mathrm{O}_{2}\right)$-was tested for the removal of DEP in a synthetic leachate simulating an MSW leachate from an open dump. The specific goal of this study was to demonstrate the impact of $\mathrm{O}_{3}$ and $\mathrm{H}_{2} \mathrm{O}_{2}$ dose during degradation on DEP removal from the leachate and the formation of ozonation intermediate by-products, in addition to changes in $\mathrm{COD}, \mathrm{pH}$, and UVC during the process. 


\section{Materials and Methods}

\subsection{Chemical Reagents and Leachate Analysis}

Leachate was prepared using DEP (>98\%), phthalic acid (>98\%), phthalic anhydride (>99\%), 4-hydroxy phthalic acid (>98\%) (Sigma Aldrich, USA), potassium hydrogen phthalate (KHP), glucose $\left(\mathrm{C}_{6} \mathrm{H}_{12} \mathrm{O}_{6}\right)$, ammonium sulfate $\left(\left(\mathrm{NH}_{4}\right)_{2} \mathrm{SO}_{4}\right)$, ammonium chloride $\left(\mathrm{NH}_{4} \mathrm{Cl}\right)$, copper sulfate $\left(\mathrm{CuSO}_{4}\right)$, lead nitrate $\left(\mathrm{Pb}\left(\mathrm{NO}_{3}\right)_{2}\right)$, nickel sulfate $\left(\mathrm{NiSO}_{4}\right)$, potassium dichromate $\left(\mathrm{K}_{2} \mathrm{Cr}_{2} \mathrm{O}_{7}\right)$, manganese sulfate $\left(\mathrm{MnSO}_{4}\right)$, zinc sulfate $\left(\mathrm{ZnSO}_{4}\right)$, propionic acid $\left(\mathrm{C}_{3} \mathrm{H}_{6} \mathrm{O}_{2}\right)$, pentanoic acid $\left(\mathrm{C}_{5} \mathrm{H}_{10} \mathrm{O}_{2}\right)$, and hexanoic acid $\left(\mathrm{C}_{6} \mathrm{H}_{12} \mathrm{O}_{2}\right)$ (Holland Moran, Israel). Analytical grade $\mathrm{H}_{2} \mathrm{O}_{2}(30 \% w / w)$ was obtained from Merck Chemicals (USA). Stock solutions were prepared by dissolving each compound in deionized water (Direct-Q3 UV System, Millipore, France). COD test kits with a measuring range of 0 to $15,000 \mathrm{mg} / \mathrm{L}$ $\mathrm{O}_{2}$ were purchased from Lavibond (England), and were based on the dichromate method and determination in a Hach spectrophotometer. The UV absorbance coefficients of the samples with different $\mathrm{H}_{2} \mathrm{O}_{2}$ concentrations were measured using a UV-visible spectrophotometer (Varian, Cary 100BIO, Australia). Spectra were collected in quartz cuvettes using a wavelength range of 200-800 nm.

\subsection{Synthetic Leachate Preparation}

The composition of the synthetic leachate was adapted from a previous study [14] and modified based on analyzed leachate samples from the Perungudi open dumpsite, Chennai, India, and previous data in the literature [15] (Table 1). The leachate characteristics used in this study simulated numerous samples of municipal solid waste, open dumpsite leachate from Chennai, India. In this leachate, diethyl phthalate (DEP) was detected at an average concentration of $17.2 \mathrm{mg} / \mathrm{L}$ in the open dumpsite. The leachate used in this study simulates young leachate.

Table 1. Synthetic leachate characteristics.

\begin{tabular}{ccc}
\hline Parameter & Model Compound & Measured Value \\
\hline $\mathrm{pH}$ & - & 7.5 \\
Chemical oxygen demand & $\mathrm{KHP}$ & $16,400 \mathrm{mg} / \mathrm{L}$ \\
Phthalate & Diethyl phthalate & $20 \mathrm{mg} / \mathrm{L}$ \\
Chloride & $\mathrm{NH}_{4} \mathrm{Cl}$ & $1500 \mathrm{mg} / \mathrm{L}$ \\
Manganese & $\mathrm{MnSO}_{4}$ & $16 \mathrm{mg} / \mathrm{L}$ \\
Zinc & $\mathrm{ZnSO}_{4}$ & $12 \mathrm{mg} / \mathrm{L}$ \\
Lead & $\mathrm{Pb}_{\left(\mathrm{NO}_{3}\right)_{2}}$ & $2 \mathrm{mg} / \mathrm{L}$ \\
Chromium & $\mathrm{K}_{2} \mathrm{Cr}_{2} \mathrm{O}_{7}$ & $1.5 \mathrm{mg} / \mathrm{L}$ \\
Copper & $\mathrm{CuSO}_{4}$ & $2.5 \mathrm{mg} / \mathrm{L}$ \\
Nickel & $\mathrm{NiSO}_{4}$ & $4.5 \mathrm{mg} / \mathrm{L}$ \\
Acetic acid & Organic acid & $7 \mathrm{mg} / \mathrm{L}$ \\
Propionic acid & Organic acid & $5 \mathrm{mg} / \mathrm{L}$ \\
Pentanoic acid & Organic acid & $1 \mathrm{mg} / \mathrm{L}$ \\
Hexanoic acid & Organic acid & $1 \mathrm{mg} / \mathrm{L}$ \\
\hline
\end{tabular}

\subsection{Experimental Setup and Procedure}

$\mathrm{O}_{3}$ experiments were performed in semi-continuous batch reactors that allowed for the continuous addition of $\mathrm{O}_{3}$ to a fixed batch of leachate with added DEP, as shown in Figure $1 . \mathrm{O}_{3}$ gas was generated using an $\mathrm{O}_{2}$-fed $\mathrm{O}_{3}$ generator (up to $4 \mathrm{~g} / \mathrm{h}$; BMT $802 \mathrm{~N}$, Germany) and the $\mathrm{O}_{2}-\mathrm{O}_{3}$ gas mixture was bubbled directly into a 100-mL glass reactor (Figure 1). The reactor was $14 \mathrm{~cm}$ in height and $3.5 \mathrm{~cm}$ in diameter, with a diffuser size of $2.35 \mathrm{~cm}^{3}$ and a nominal pore size of $25 \mu \mathrm{m}$, as described in a previous study [16]. An $\mathrm{O}_{3}$-flow control valve was used to determine the $\mathrm{O}_{3}$ flow, which was maintained at 0.2 $\mathrm{L} / \mathrm{min}$ operated under ambient conditions. 


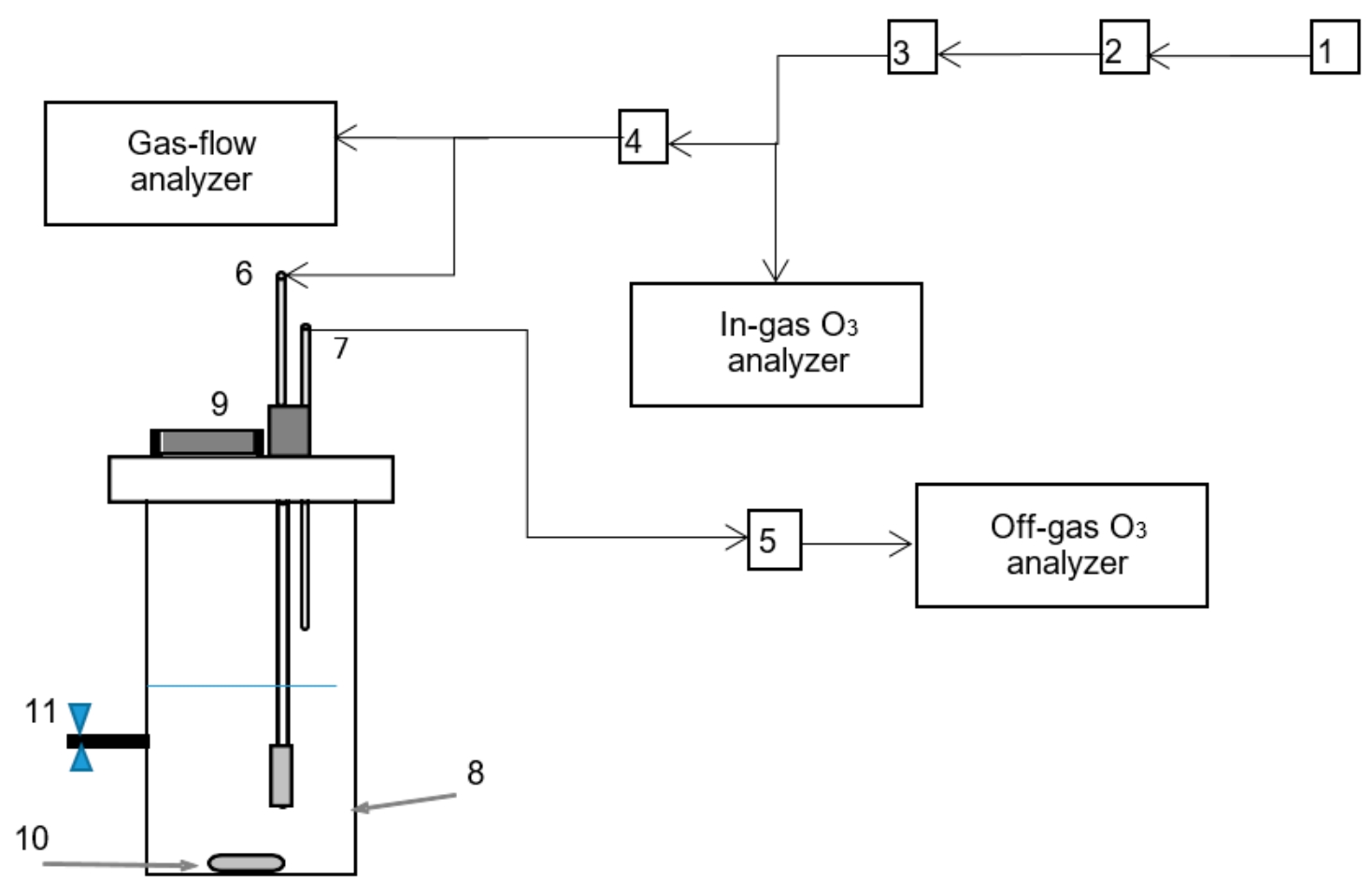

Figure 1. Semi-batch $\mathrm{O}_{3}$ system experimental setup: (1) $\mathrm{O}_{2}$ gas and flow-rate gauge; (2) air drier and humidity indicator; (3) $\mathrm{O}_{3}$ generator; (4) gas inlet gauge; (5) air drier for $\mathrm{O}_{3}$-saturated air; $(6,7)$ gas inlet and outlet, respectively; (8) $\mathrm{O}_{3}$ diffuser; (9) solution inlet; (10) magnetic stir bar; and (11) sampling port.

The transferred $\mathrm{O}_{3}$ dose (TOD) is an empirical parameter for determining the accumulated amount of $\mathrm{O}_{3}$ transferred to the water that reacts with the examined material. Although this parameter is usually used for the prediction of micropollutant elimination during the ozonation of municipal wastewater effluents, it can also serve for the determination of $\mathrm{O}_{3}$ accumulation in leachate. Here, the $\mathrm{O}_{3}$ dose was estimated using continuous measurements of the $\mathrm{O}_{3}$ concentration in the gas phase at the inlet and outlet (off gas) of the reactor:

$$
\text { Transferred Ozone Dose }\left(\frac{\mathrm{mgO}_{3}}{L}\right)=\frac{\sum\left\{\left(C_{\mathrm{O}_{3}, \text { in }}-C_{\mathrm{O}_{3, \text { out }}}\right)_{m g / L} \text {. } \text { gas flowrate }_{L / \text { min }}\right\} \times d t_{\text {min }}}{\text { volume }_{\mathrm{L}}}
$$

where $\mathrm{C}_{\mathrm{O}_{3} \text {,in }}$ is the $\mathrm{O}_{3}$ concentration in the inlet stream, $\mathrm{C}_{\mathrm{O}_{3}, \text { out }}$ is the $\mathrm{O}_{3}$ concentration in the outlet stream, representing the unreacted $\mathrm{O}_{3}$ exiting the reactor, and $d t$ is the time interval between measurements, set at $1 \mathrm{~min}$.

DEP $(20 \mathrm{mg} / \mathrm{L})$ was spiked into the synthetic leachate with the addition of $0,5,10,20,30,40$, and $50 \mathrm{mg} / \mathrm{L}$ of $\mathrm{H}_{2} \mathrm{O}_{2}$ to study the impact of $\mathrm{H}_{2} \mathrm{O}_{2}$ on DEP degradation along with the generated intermediate transformation products. The parameters recorded with the $\mathrm{O}_{3}$ and $\mathrm{O}_{3} / \mathrm{H}_{2} \mathrm{O}_{2}$ processes were $\mathrm{COD}, \mathrm{UVC}$, and $\mathrm{pH}$. The impact of $\mathrm{OH}$ radicals on DEP-degradation kinetics using direct ozonation was determined in the presence of the radical scavenger tert-butanol $(t-B u O H)(50,100,150$, $200 \mathrm{mM}$ ). The radical probe compound para-chlorobenzoic acid (pCBA) was used at concentrations of $10 \mathrm{mg} / \mathrm{L}$ and $20 \mathrm{mg} / \mathrm{L}$ to determine the steady-state $\mathrm{OH}$ radical concentration for the degradation of DEP.

\subsection{High-Performance Liquid Chromatography (HPLC) Analysis}

An Agilent 1100 series HPLC system with single-wavelength UV detector was used for the analysis of both DEP and pCBA. The column was a Kinetex C18-XB column, $100 \times 3.0 \mathrm{~mm}, 2.6 \mu \mathrm{m}$ at $40^{\circ} \mathrm{C}$, with a Gemini $\mathrm{C} 184 \times 2.0 \mathrm{~mm}$ pre-column guard. The pump was set to an isocratic program of 
$40 \%$ water, $60 \% \mathrm{MeOH}$, and $0.1 \%$ formic acid $(v / v)$, at a flow rate of $0.5 \mathrm{~mL} / \mathrm{min}$. The injection volume was $30 \mu \mathrm{L}$ and the detector wavelength was set to $228 \mathrm{~nm}$ for DEP (retention time $3.0 \mathrm{~min}$ ) and $243 \mathrm{~nm}$ for pCBA (retention time $2.5 \mathrm{~min}$ ).

\subsection{LC-MS Analysis}

LC-MS analysis of the DEP degradation products phthalic acid and p-hydroxy phthalic acid (obtained after sample treatment with $\mathrm{O}_{3} / \mathrm{H}_{2} \mathrm{O}_{2}$ ) was performed using HPLC (Agilent 1100) coupled to MS (Q-Tof, Waters, model Premier) via an electrospray ionization (ESI) interface in positive mode, using the Kinetex $\mathrm{C} 18-\mathrm{XB}$ column. The column temperature was set to $40{ }^{\circ} \mathrm{C}$, the flow rate to 0.5 $\mathrm{mL} / \mathrm{min}$, and the injection volume was $30 \mu \mathrm{L}$. The HPLC mobile phase consisted of water (A) and methanol (B) with $0.1 \%$ formic acid. The elution gradient was initiated with $20 \%$, held for 2 min, increased to $65 \%$ over $11 \mathrm{~min}$, and then held at $65 \%$ for $5 \mathrm{~min}$.

\section{Results and Discussion}

\subsection{DEP Removal in $\mathrm{O}_{3}$ and $\mathrm{O}_{3} / \mathrm{H}_{2} \mathrm{O}_{2}$ Processes}

Synthetic leachate was spiked with $0.5 \mathrm{M}(20 \mathrm{mg} / \mathrm{L}) \mathrm{DEP}$ at $\mathrm{pH} 7.5$ with various $\mathrm{H}_{2} \mathrm{O}_{2}$ concentrations $(0,5,10,20,30,40$, and $50 \mathrm{mg} / \mathrm{L})$ and ozonated to determine the ozonation kinetics. Figure 2 shows the degradation of DEP with the $\mathrm{O}_{3}$ and $\mathrm{O}_{3} / \mathrm{H}_{2} \mathrm{O}_{2}$ processes. The DEP concentration decreased by $21 \%$ with $120 \mathrm{~min}$ of ozonation only (TOD $=4971 \mathrm{mg} / \mathrm{L}$ ). To increase the rate of DEP degradation, $\mathrm{H}_{2} \mathrm{O}_{2}$ was added to accelerate the production of $\mathrm{OH}$ radicals for the efficient degradation of DEP from leachate using the peroxone process.

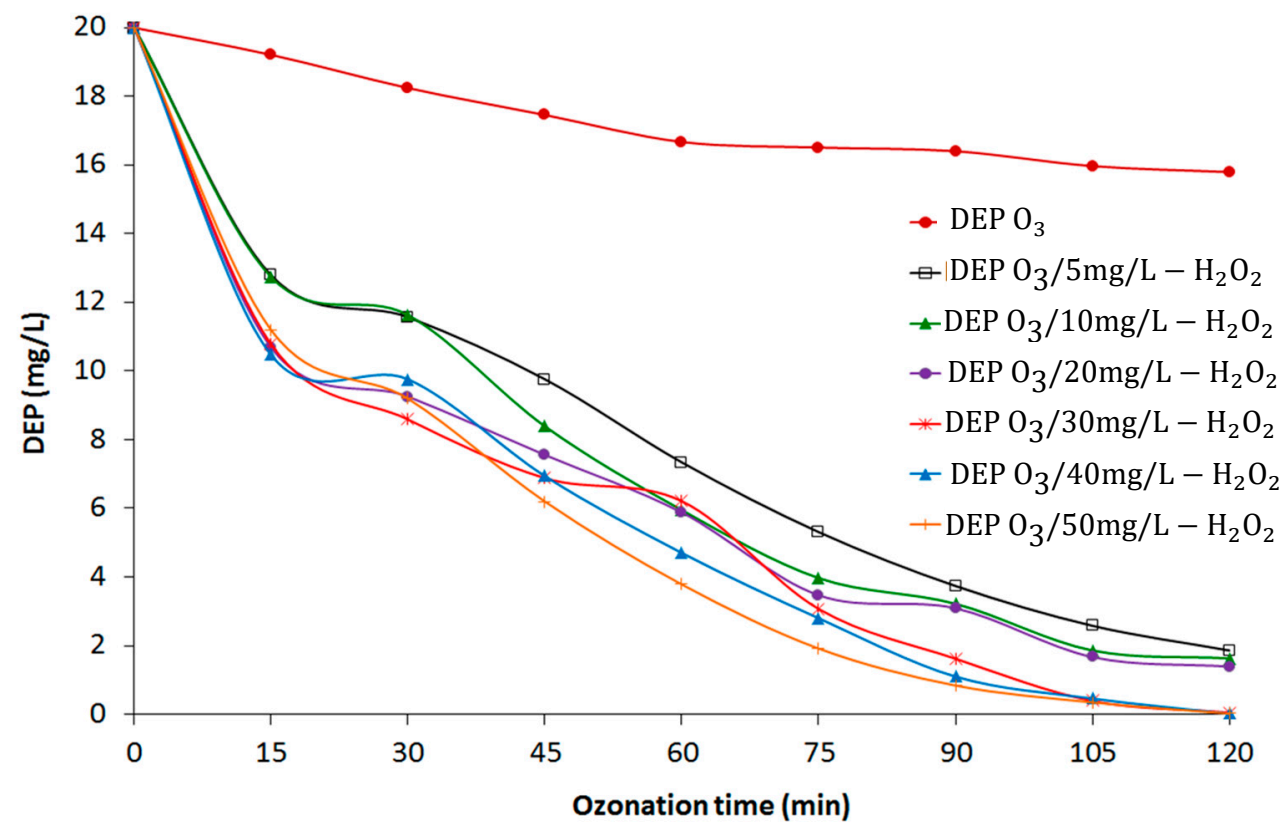

Figure 2. Diethyl phthalate (DEP) removal with peroxone process.

The degradation rate of DEP increased with increasing $\mathrm{H}_{2} \mathrm{O}_{2}$ concentration. The addition of 0 to $50 \mathrm{mg} / \mathrm{L} \mathrm{H}_{2} \mathrm{O}_{2}$ increased the degradation rate from $21 \%$ to $99.9 \%$ at $120 \mathrm{~min}$ of ozonation. The reaction process can be explained by the following equations, where in Equation (2), the conjugate base of the $\mathrm{H}_{2} \mathrm{O}_{2}$ concentration is $\mathrm{pH}$ dependent.

$$
\begin{gathered}
\mathrm{OH}^{-}+\mathrm{O}_{3} \rightarrow \mathrm{O}_{2}+\mathrm{HO}_{2}^{-} \stackrel{\mathrm{H}+}{\leftrightarrow} \mathrm{H}_{2} \mathrm{O}_{2} \\
\mathrm{HO}_{2}^{-}+\mathrm{O}_{3} \rightarrow \mathrm{HO}_{2}^{-}+\mathrm{O}_{3}^{--}
\end{gathered}
$$




$$
\begin{gathered}
\mathrm{HO}_{2} \leftrightarrow \mathrm{H}^{+}+\mathrm{O}_{2}^{--} \\
\mathrm{O}_{2}^{--}+\mathrm{O}_{3} \rightarrow \mathrm{O}_{2}+\mathrm{O}_{3}^{--} \\
\mathrm{O}_{3}^{--}+\mathrm{H}^{+} \rightarrow \bullet \mathrm{OH} \text { (hydroxy) }+\mathrm{O}_{2} \\
\bullet \mathrm{OH}+\mathrm{O}_{3} \rightarrow \mathrm{HO}_{2} \text { (proxy) }+\mathrm{O}_{2} \\
\mathrm{DEP}+\mathrm{O}_{3} \rightarrow \text { Products }+ \text { Intermediate compounds } \\
\mathrm{DEP}+\bullet \mathrm{OH} \rightarrow \text { Products }+ \text { Intermediate compounds } \\
\bullet \mathrm{OH}+\text { Intermediate products } \rightarrow \mathrm{CO}_{2}+\mathrm{H}_{2} \mathrm{O}
\end{gathered}
$$

The addition of $\mathrm{H}_{2} \mathrm{O}_{2}$ to $\mathrm{O}_{3}$ results in $\mathrm{O}_{3}$ decomposition and $\mathrm{OH}$ radical $(\bullet \mathrm{OH})$ formation. At high $\mathrm{pH}$, the concentration of $\mathrm{HO}_{2}{ }^{-}$increases and hence the concentration of $\bullet \mathrm{OH}$ increases [13]. At an acidic $\mathrm{pH}$, ozone reacts selectively and slowly with organics, whereas with increasing $\mathrm{pH}$ ozone decomposition is accelerated and radical reactions occur via the reaction of ozone with some compounds known as initiators, such as hydrogen peroxide $\left(\mathrm{H}_{2} \mathrm{O}_{2}\right)$ [16]. Reactions for $\mathrm{O}_{3} / \mathrm{H}_{2} \mathrm{O}_{2}$ are similar to those for $\mathrm{O}_{3}$ alone with added $\mathrm{H}_{2} \mathrm{O}_{2}$ dosing the system. The peroxone reaction is:

$$
\mathrm{H}_{2} \mathrm{O}_{2}+\mathrm{H}_{2} \mathrm{O} \leftrightarrow \mathrm{HO}_{2-}+\mathrm{H}_{3} \mathrm{O}+\mathrm{O}_{3}+\mathrm{HO}_{2-} \rightarrow \bullet \mathrm{OH}+\mathrm{O}_{2-}+\mathrm{O}_{2} .
$$

An increase in DEP degradation with the addition of $\mathrm{H}_{2} \mathrm{O}_{2}$ to the ozonation process was due to the formation of $\mathrm{OH}$ radicals. According to Figure 2, the optimal $\mathrm{H}_{2} \mathrm{O}_{2}$ concentration was $\approx 40 \mathrm{mg} / \mathrm{L}$ with almost complete DEP removal $(99.9 \%)$. No additional decrease in DEP concentration was obtained with the addition of $50 \mathrm{mg} / \mathrm{L} \mathrm{H}_{2} \mathrm{O}_{2}$ to the peroxone treatment.

Supplementary Figure $\mathrm{S} 2$ shows the change in $\mathrm{pH}$ during the peroxone process. During the ozonation treatment, the $\mathrm{pH}$ gradually decreased from 7.5 to 5.1 with time and with the addition of $\mathrm{H}_{2} \mathrm{O}_{2}$. Alkaline $\mathrm{pH}$ enhances the formation of $\mathrm{OH}$ radicals as more hydroxide ions are present (Equations (12) and (13)). These hydroxide ions initiate $\mathrm{O}_{3}$ decay.

$$
\begin{gathered}
\mathrm{O}_{3}+\mathrm{OH}^{-} \rightarrow \mathrm{HO}_{2}^{-}+\mathrm{O}_{2} \\
\mathrm{O}_{3}+\mathrm{HO}_{2}^{-} \rightarrow \bullet \mathrm{OH}+\mathrm{O}_{2}^{-}+\mathrm{O}_{2}
\end{gathered}
$$

The produced $\bullet \mathrm{OH}$ (Equation (13)) can subsequently introduce further chemical reactions with $\mathrm{O}_{3}$, resulting in an increased $\mathrm{OH}$ radical formation. In addition, the $\mathrm{pH}$ of the wastewater influences the acid/base equilibria of some compounds, as well as the $\mathrm{O}_{3}$ reaction rate.

\subsection{Effect of $\mathrm{O}_{3} / \mathrm{H}_{2} \mathrm{O}_{2}$ Process on $\mathrm{COD}, \mathrm{UVC}$, and $\mathrm{pH}$}

Leachate is characterized by a high concentration of organic matter, as determined by COD value, which refers to the amount of specific oxidant reacting with the sample under controlled conditions [17]. In this study, the initial COD value in the leachate was $\approx 16,400 \mathrm{mg} / \mathrm{L}$. The mixed solid wastes that were deposited in the open dump in a non-segregating method produced a high COD and probably required a high concentration of oxidant to degrade the complex compounds and increase the leachate biodegradability. Figures 3 and 4 show the effects of $\mathrm{O}_{3}$ and $\mathrm{O}_{3} / \mathrm{H}_{2} \mathrm{O}_{2}$ on COD and the correlation between COD and UVC, respectively. Figure 3 illustrates that only $12.2 \%$ of the COD was removed, from $16,400 \mathrm{mg} / \mathrm{L}$ to $14,400 \mathrm{mg} / \mathrm{L}$, during $120 \mathrm{~min}$ of $\mathrm{O}_{3}$ treatment. The presence of $\mathrm{H}_{2} \mathrm{O}_{2}(5,10,20$, 30, 40, and $50 \mathrm{mg} / \mathrm{L})$ resulted in increased COD removal, from $15.9 \%\left(\mathrm{O}_{3} / 5 \mathrm{mg} / \mathrm{L} \mathrm{H}_{2} \mathrm{O}_{2}\right)$ to $68.9 \%$ $\left(\mathrm{O}_{3} / 50 \mathrm{mg} / \mathrm{L} \mathrm{H}_{2} \mathrm{O}_{2}\right)$ for a final COD concentration after $120 \mathrm{~min}$ of $\approx 5800 \mathrm{mg} / \mathrm{L}$. Removal of COD indicates that the addition of $\mathrm{H}_{2} \mathrm{O}_{2}$ increased the formation of $\mathrm{OH}$ radicals, which in turn mineralized the organic compounds. Tizaoui et al. reported an improvement in COD removal from $27 \%$ to $48 \%$ using semi-batch $\mathrm{O}_{3}$ and $\mathrm{O}_{3} / 2000 \mathrm{mg} / \mathrm{L} \mathrm{H}_{2} \mathrm{O}_{2}$, respectively [18], which was a considerably higher amount of $\mathrm{H}_{2} \mathrm{O}_{2}$ than that used in the present study. 


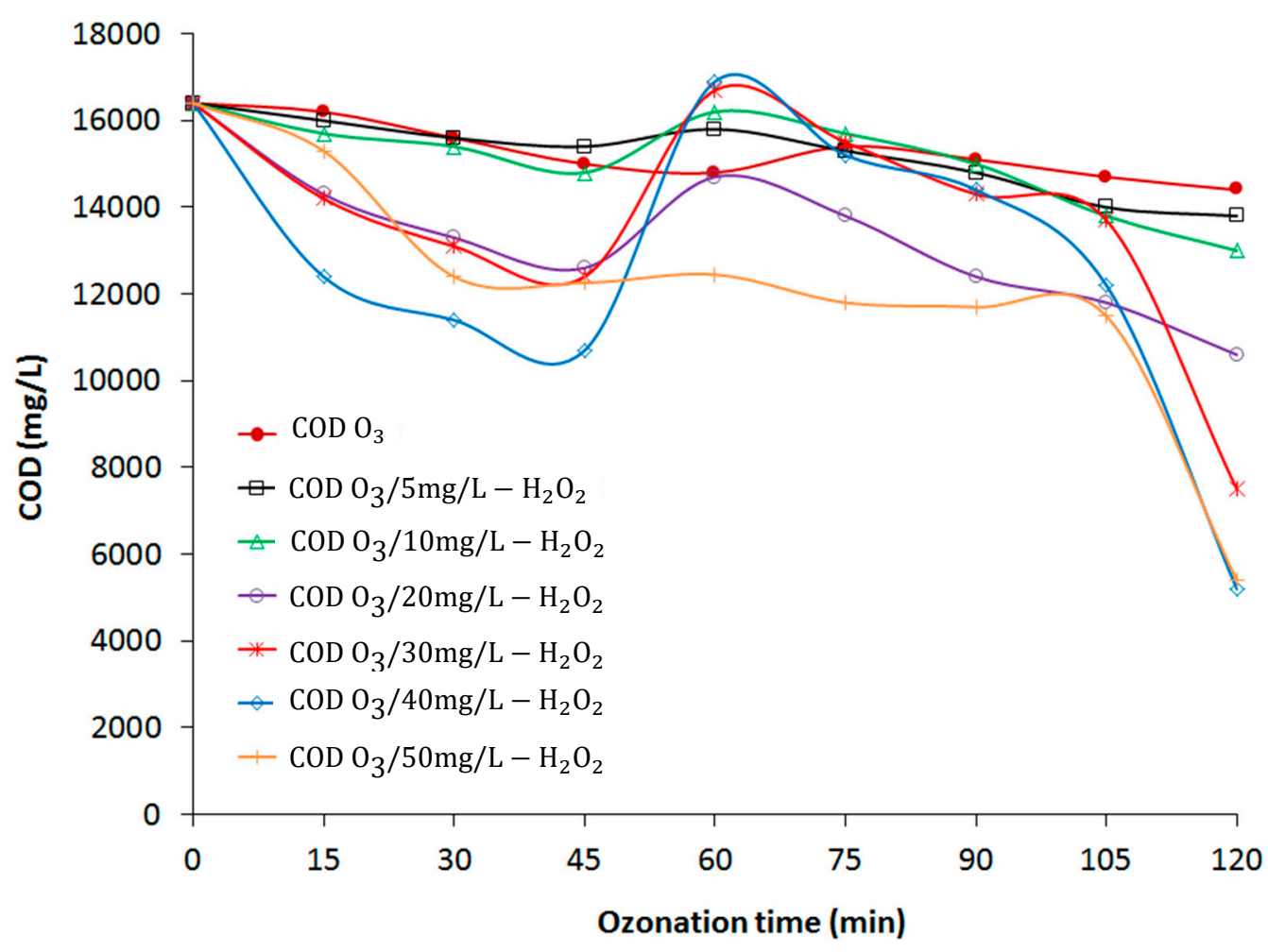

Figure 3. Influence of $\mathrm{O}_{3}$ and $\mathrm{O}_{3} / \mathrm{H}_{2} \mathrm{O}_{2}$ on chemical oxygen demand (COD) removal.

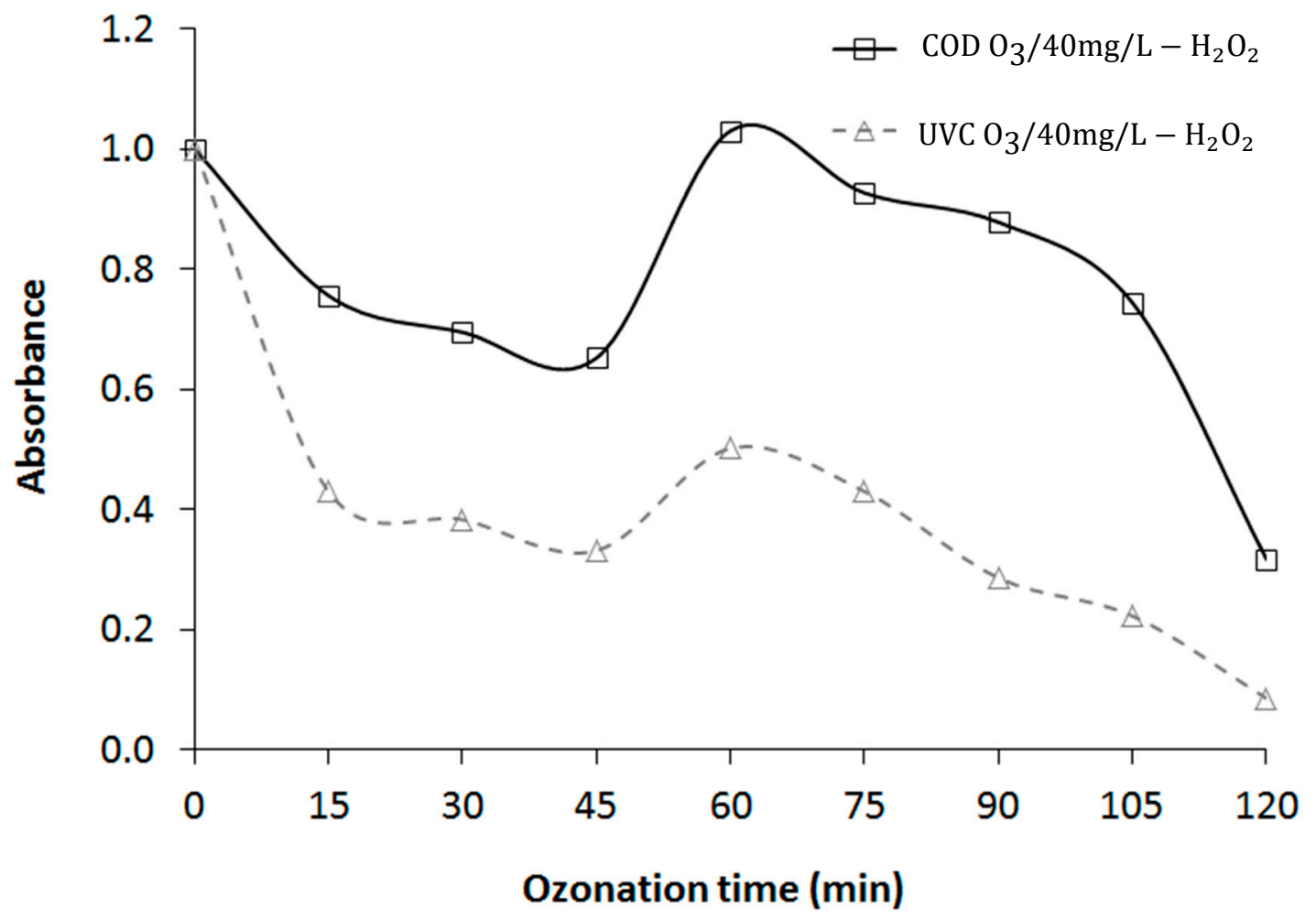

Figure 4. COD versus UVC for $\mathrm{O}_{3}$ with $40 \mathrm{mg} / \mathrm{L} \mathrm{H}_{2} \mathrm{O}_{2}$.

Figure 3 shows that the COD decreased gradually during the initial $\mathrm{O}_{3}$ and $\mathrm{O}_{3} / \mathrm{H}_{2} \mathrm{O}_{2}$ processes due to the availability of $\mathrm{OH}$ radicals. Further, an increase in $\mathrm{COD}$ concentration was observed at $60 \mathrm{~min}$ (except for the $\mathrm{O}_{3}$ treatment alone), indicating the formation of organic acids during DEP degradation by AOP [13]. As the peroxone treatment continued, COD decreased further due to additional oxidation 
of the intermediates by $\mathrm{OH}$ radicals to the final COD. The COD removal with $40 \mathrm{mg} / \mathrm{L} \mathrm{H}_{2} \mathrm{O}_{2}$ was similar to that with $50 \mathrm{mg} / \mathrm{L} \mathrm{H}_{2} \mathrm{O}_{2}$, showing that an increased $\mathrm{H}_{2} \mathrm{O}_{2}$ concentration does not always result in increased COD-removal rates. The increase in $\mathrm{H}_{2} \mathrm{O}_{2}$ concentration leads to a change in its role from $\mathrm{OH}$ radical producer to inhibitor of $\mathrm{O}_{3}$ decomposition by free radicals [19].

$$
\mathrm{O}_{3}+\mathrm{HOO}^{-} \rightarrow \mathrm{O}_{3}^{\cdot-}+\mathrm{HO}_{2}
$$

According to Peretz et al. [16], increasing the concentration of $\mathrm{H}_{2} \mathrm{O}_{2}$ can cause further decomposition of ozone while yielding the ozonide radical anion $\mathrm{O}_{3}$, which could be detected as dissolved ozone. This may result in a pseudo increase in the dissolved ozone concentration. Similarly, UVC at $254 \mathrm{~nm}$ followed the COD removal trend, probably due to its high concentration, for an optimum dosage of $\mathrm{O}_{3} / 40 \mathrm{mg} / \mathrm{L} \mathrm{H}_{2} \mathrm{O}_{2}$ (Figure 4).

Numerous studies have shown that UVC can be used to probe the micropollutant removal in secondary wastewater effluent, e.g., to track carbamazepine in a secondary effluent [20]. However, the current study showed that in the complex leachate matrix, it was not possible to track the degradation of the target pollutant using UVC. Leachate has many complex organic substances and heavy metals that interfere with pollutant removal, and Figure 4 proves that the UVC reflected the degradation of COD in leachate, indicating that it cannot be used as a tracking model for DEP removal.

\subsection{Effect of $t-B u O H$ in the Kinetic Evaluation}

The radical scavenger $\mathrm{t}-\mathrm{BuOH}$ was added to quench the formation of $\mathrm{OH}$ radicals during the ozonation process because the rate constant of $\mathrm{O}_{3}$ for DEP is very low $\left(\mathrm{K}_{\mathrm{O}_{3}}=0.06-0.1 \mathrm{M}^{-1} \mathrm{~s}^{-1}\right)$ and maximum DEP removal was achieved using the $\mathrm{OH}$ radicals. To determine the impact of direct ozonation on DEP degradation, $\mathrm{t}-\mathrm{BuOH}$ was added to the leachate at $50 \mathrm{mM}, 100 \mathrm{mM}, 150 \mathrm{mM}$, and $200 \mathrm{mM}$. Figure 5 shows the removal of DEP in leachate with different concentrations of $\mathrm{t}-\mathrm{BuOH}$ compared to the direct ozonation of the leachate. Ozonation alone yielded $\approx 21 \%$ DEP removal from the leachate $(120 \mathrm{~min}$; TOD $=4971 \mathrm{mg} / \mathrm{L})$, whereas addition of $\mathrm{t}-\mathrm{BuOH}$ to the leachate increased the removal rate of DEP instead of decreasing it.

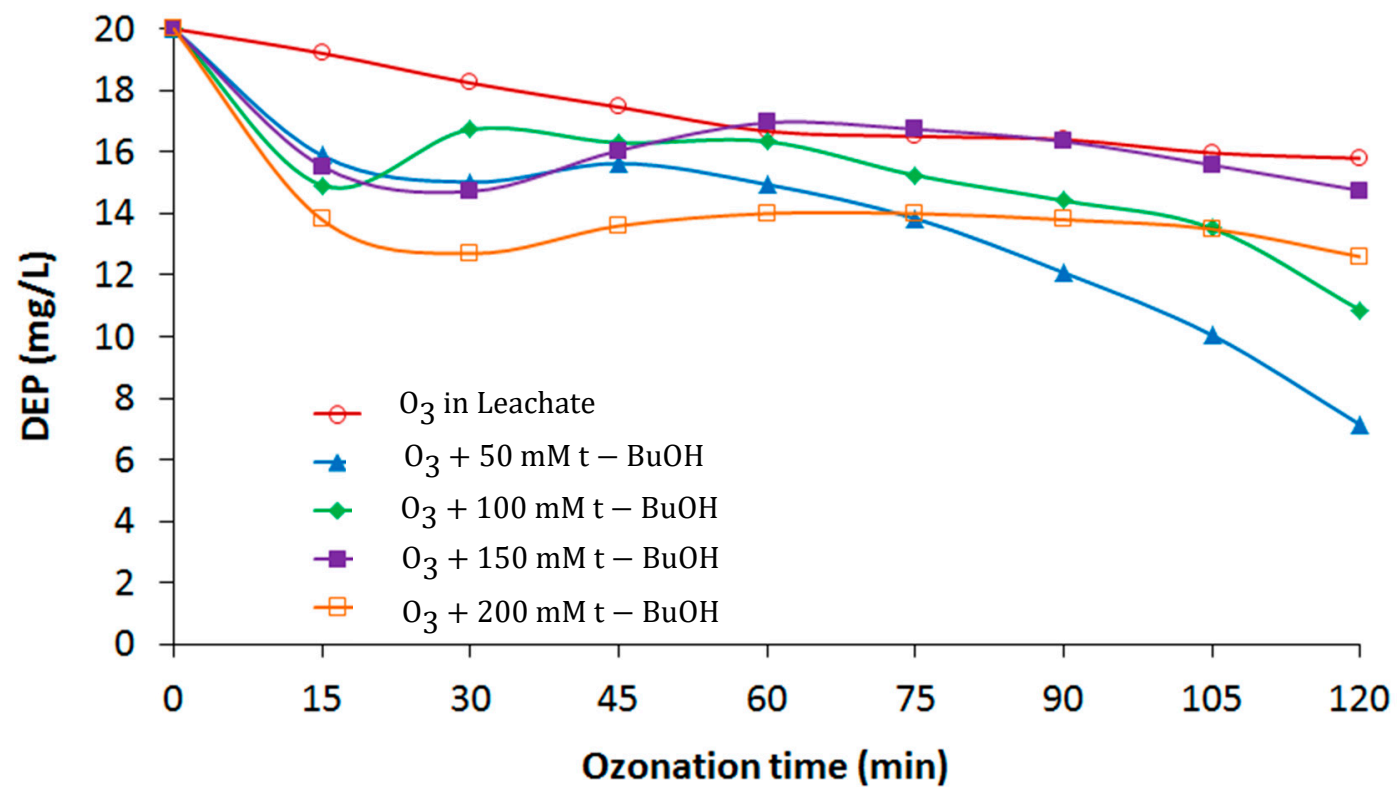

Figure 5. Diethyl phthalate (DEP) removal in leachate for different tert-butanol (t-BuOH) concentrations.

From Figure 5, the addition of $50 \mathrm{mM}$ t-BuOH gave $64.3 \%$ DEP removal; increasing the t-BuOH concentration to $150 \mathrm{mM}$ resulted in less DEP removal ( $\approx 26.3 \%)$, and $200 \mathrm{mM} \mathrm{t}-\mathrm{BuOH}$ then increased the DEP degradation to a final concentration of $12.6 \mathrm{mg} / \mathrm{L}$ after $120 \mathrm{~min}$. Thus, even after the addition of 
the $\mathrm{OH}$ radical scavenger, there was more degradation of DEP than with ozonation alone. The addition of $\mathrm{t}-\mathrm{BuOH}$ surprisingly did not suppress the $\mathrm{OH}$ radical formation. Instead, the addition of $\mathrm{t}-\mathrm{BuOH}$ enhanced the DEP removal in comparison to the ozone treatment without the added $t-\mathrm{BuOH}$. $\mathrm{t}-\mathrm{BuOH}$ may contribute to the formation of transesterification products, which in turn may enhance the $\mathrm{OH}$ radical's formation [21] and the degradation of DEP. Transesterification is the process of exchanging the organic group of an ester with the organic group of an alcohol. Consequently, in the leachate matrix, $\mathrm{t}-\mathrm{BuOH}$ cannot be used to evaluate the impact of direct ozonation on DEP degradation.<smiles>[R]OC([R])=O</smiles>

\subsection{OH Radical Exposure}

$\mathrm{O}_{3}$ exposure $\int\left[\mathrm{O}_{3}\right] d t$ and $\mathrm{OH}$ radical exposure $\int[\cdot \mathrm{OH}] d t$, under the $\mathrm{R}_{\mathrm{ct}}$ concept, were monitored during ozonation by the depletion rate of an in situ $\mathrm{OH}$ radical probe compound (pCBA). $\mathrm{R}_{\mathrm{ct}}$ represents the ratio of the $\mathrm{OH}$ radical concentration to the $\mathrm{O}_{3}$ concentration in a given body of water/wastewater $\left(\mathrm{R}_{\mathrm{ct}}=[\bullet \mathrm{OH}] /\left[\mathrm{O}_{3}\right]\right)[22]$. Degradation of pCBA in leachate can be predicted using the $\mathrm{O}_{3}$ kinetics and $\mathrm{R}_{\mathrm{ct}}$. The $\mathrm{OH}$ radical and $\mathrm{O}_{3}$ exposures in a steady state are determined specifically for every application since they are directly affected by water-quality parameters:

$$
\frac{c}{c_{0}}=\exp \left(-k_{\mathrm{O}_{3}} \int\left[\mathrm{O}_{3}\right] d t-k \cdot \mathrm{OH} \int[\cdot \mathrm{OH}] d t\right)
$$

where $k_{\mathrm{O}_{3}}$ represents the rate constant of $\mathrm{O}_{3}$ and $k_{\mathrm{OH}}$ represents the rate constant of $\mathrm{OH}$ radicals for the $\mathrm{O}_{3}$ probe compound pCBA. The direct reaction of the resistant tracer with $\mathrm{O}_{3}$ is negligible; hence its contribution to compound removal can be eliminated from the equation, according to Equation (15). The "OH-radical probe method" involves an indirect determination of oxidant exposures, where the $\mathrm{OH}$ radical exposure is back-calculated from the removal of the $\mathrm{O}_{3}$-resistant probe compound (pCBA) [22-25]:

$$
\frac{c}{c_{0}}=\exp \left(-k \cdot \mathrm{OH} \int[\cdot \mathrm{OH}] d t\right)
$$

However, an accurate $\mathrm{O}_{3}$-exposure measurement in wastewater effluent is problematic since the rapid reaction of effluent organic matter and even effluent particles [20] with $\mathrm{O}_{3}$ results in rapid $\mathrm{O}_{3}$ depletion in the first milliseconds of the reaction [23]. An alternative concept, referred to here as the " $\mathrm{O}_{3}$ probe method," suggests that $\mathrm{O}_{3}$ exposure can be back-calculated from the removal of an internal tracer (a moderately or rapidly reacting probe compound) that reacts with both $\mathrm{O}_{3}$ and $\mathrm{OH}$ radicals following the ozonation of wastewater effluents. DEP cannot be used as the internal probe compound for $\mathrm{OH}$ radical estimation due its degradation to both superoxide and peroxy radicals [26].

Using the $\mathrm{R}_{\mathrm{ct}}$ concept, the $\mathrm{OH}$ radical probe compound $\mathrm{pCBA}$ was spiked into the leachate (at $10 \mathrm{mg} / \mathrm{L}$ and $20 \mathrm{mg} / \mathrm{L}$ ) containing $20 \mathrm{mg} / \mathrm{L} \mathrm{DEP}$, and its final concentration was determined after ozonation for different time intervals (Figure 6). Table 2 shows the $\mathrm{OH}$ exposure for 10 and $20 \mathrm{mg} / \mathrm{L}$ pCBA, respectively; with $\mathrm{K}_{\mathrm{O}_{3}}$ and $\mathrm{K}_{\mathrm{OH}}$ values for the $\mathrm{O}_{3}$ treatment of $0.15 \mathrm{M}^{-1} \mathrm{~s}^{-1}$ and $5 \times 10^{9} \mathrm{M}^{-1} \mathrm{~s}^{-1}$. 


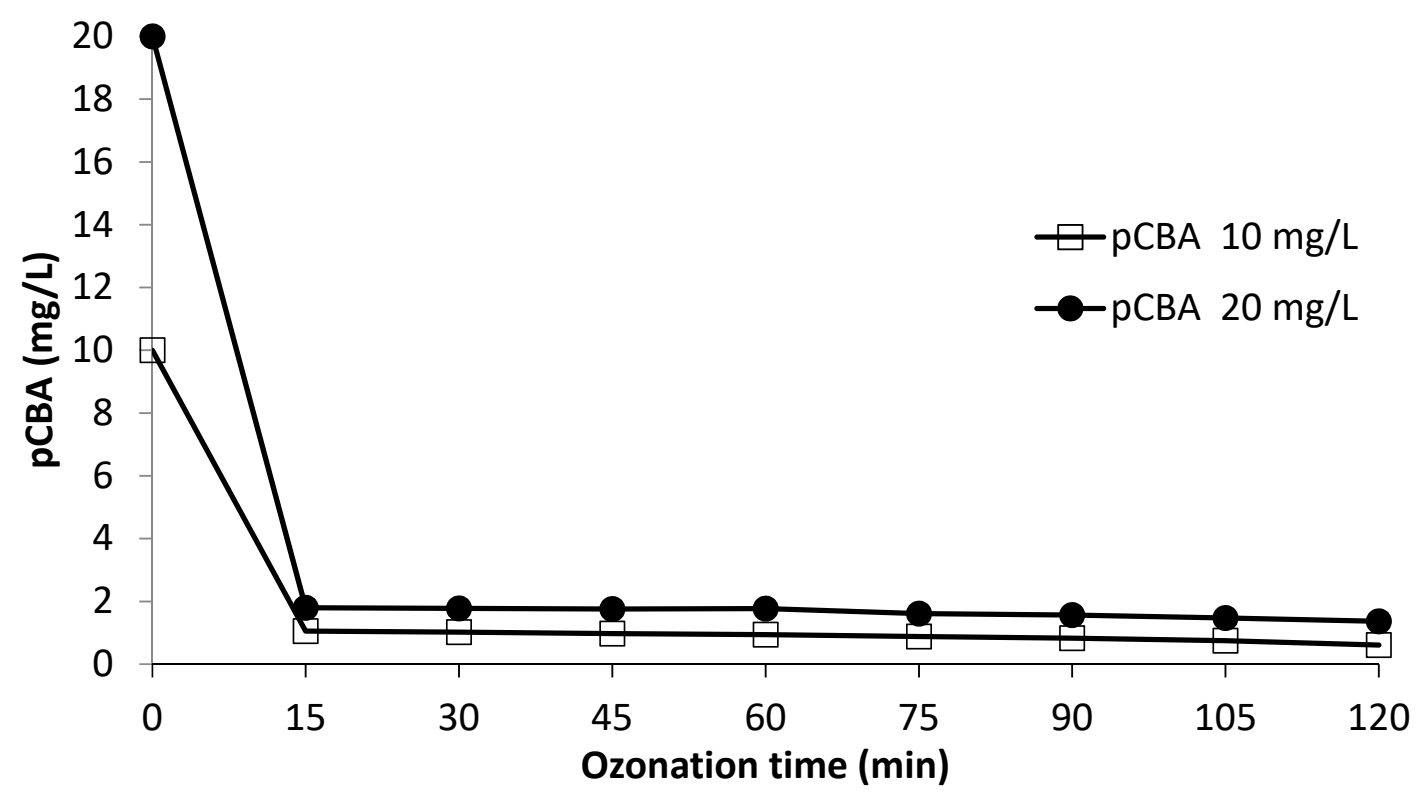

Figure 6. Para-chlorobenzoic acid (pCBA) degradation for a semi-batch $\mathrm{O}_{3}$ process.

Table 2. $\mathrm{OH}$ radical exposure for $\mathrm{O}_{3}$ treatment.

\begin{tabular}{ccccc}
\hline Ozonation Time (min) & pCBA (10 $\mathbf{~ g / L ) ~}$ & OH Exposure & pCBA (20 $\mathbf{~ g / / L ) ~}$ & OH Exposure \\
\hline 0 & 10 & 0 & 20 & 0 \\
15 & 1.06 & $4.50 \times 10^{-10}$ & 1.8 & $4.82 \times 10^{-10}$ \\
30 & 1.02 & $4.57 \times 10^{-10}$ & 1.78 & $4.84 \times 10^{-10}$ \\
45 & 0.98 & $4.65 \times 10^{-10}$ & 1.76 & $4.86 \times 10^{-10}$ \\
60 & 0.94 & $4.73 \times 10^{-10}$ & 1.77 & $4.85 \times 10^{-10}$ \\
75 & 0.88 & $4.86 \times 10^{-10}$ & 1.61 & $5.04 \times 10^{-10}$ \\
90 & 0.83 & $4.98 \times 10^{-10}$ & 1.57 & $5.10 \times 10^{-10}$ \\
105 & 0.75 & $5.18 \times 10^{-10}$ & 1.48 & $5.21 \times 10^{-10}$ \\
120 & 0.61 & $5.60 \times 10^{-10}$ & 1.37 & $5.37 \times 10^{-10}$ \\
\hline
\end{tabular}

pCBA: para-chlorobenzoic acid.

\subsection{Formation of Intermediate Transformation Products}

DEP degradation contributes to the formation of various byproducts during the $\mathrm{O}_{3}$ and $\mathrm{O}_{3} / \mathrm{H}_{2} \mathrm{O}_{2}$ treatment processes, along with the production of organic acids, such as succinic acid, malonic acid, and glutaric acid [13], as well as three possible intermediate products: phthalic acid, 4-hydroxy phthalic acid, and phthalic anhydride [13]. Figures 7 and 8 show the trend analysis of the areas for phthalic acid and 4-hydroxy phthalic acid, respectively. Intermediate product formation occurs upon DEP degradation due to cleavage of its chain and hydroxylation of the aromatic ring.

Previous studies have shown that during ozonation [10], DEP does not readily react with $\mathrm{O}_{3}$ molecules, indicating a very low reaction-rate constant. Consequently, $\mathrm{O}_{3}$ decay via DEP degradation results in the formation of intermediate DEP-oxidation products. During the 120-min $\mathrm{O}_{3}$ treatment, there was a consistent increment of phthalic acid (Figure 7), while 4-hydroxy phthalic acid was not produced using $\mathrm{O}_{3}$ alone (Figure 8), possibly due to a low concentration or absence of $\mathrm{OH}$ radicals that are expected to attack the aromatic ring at the para position. 


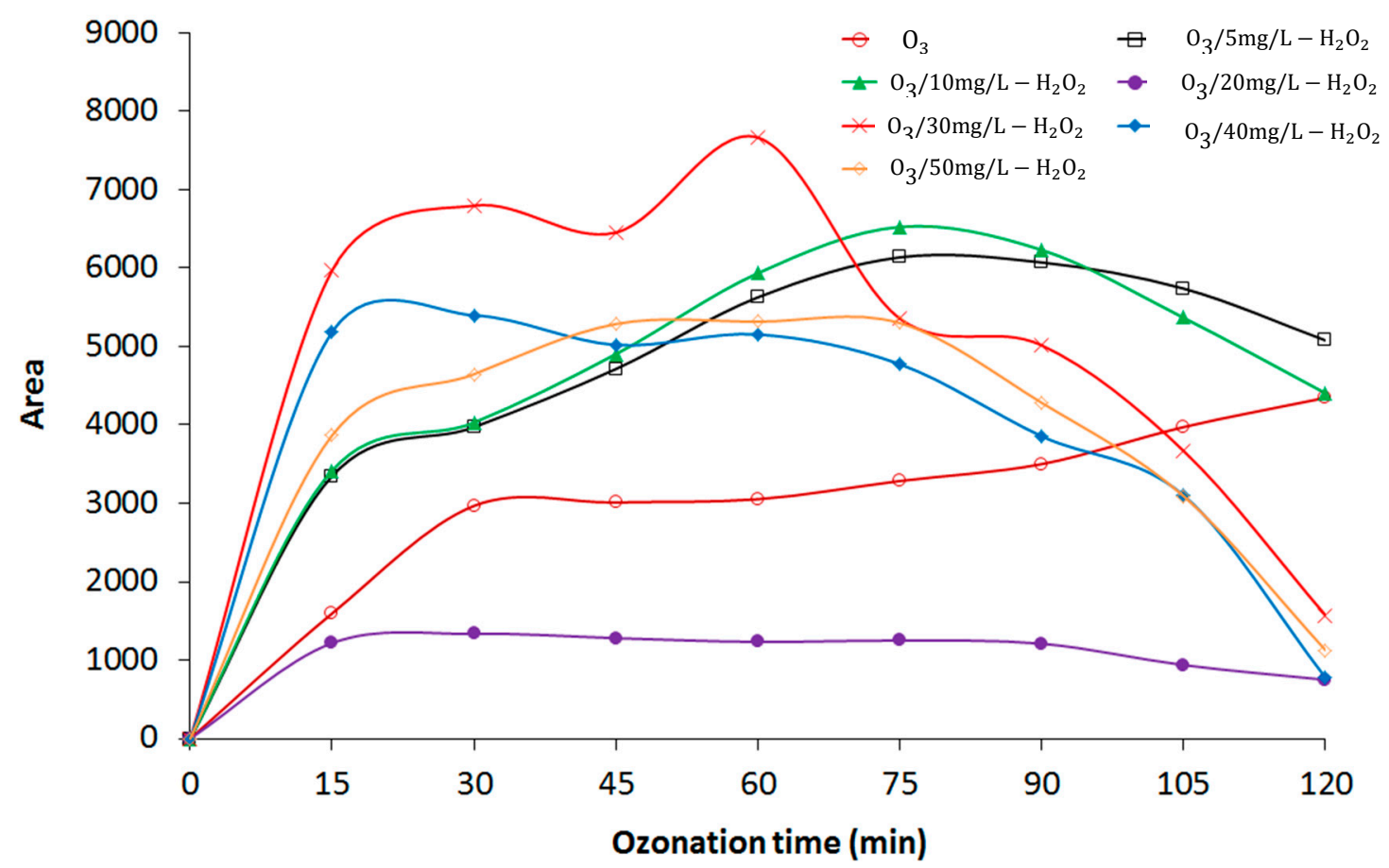

Figure 7. Phthalic acid as an intermediate diethyl phthalate (DEP) degradation product.

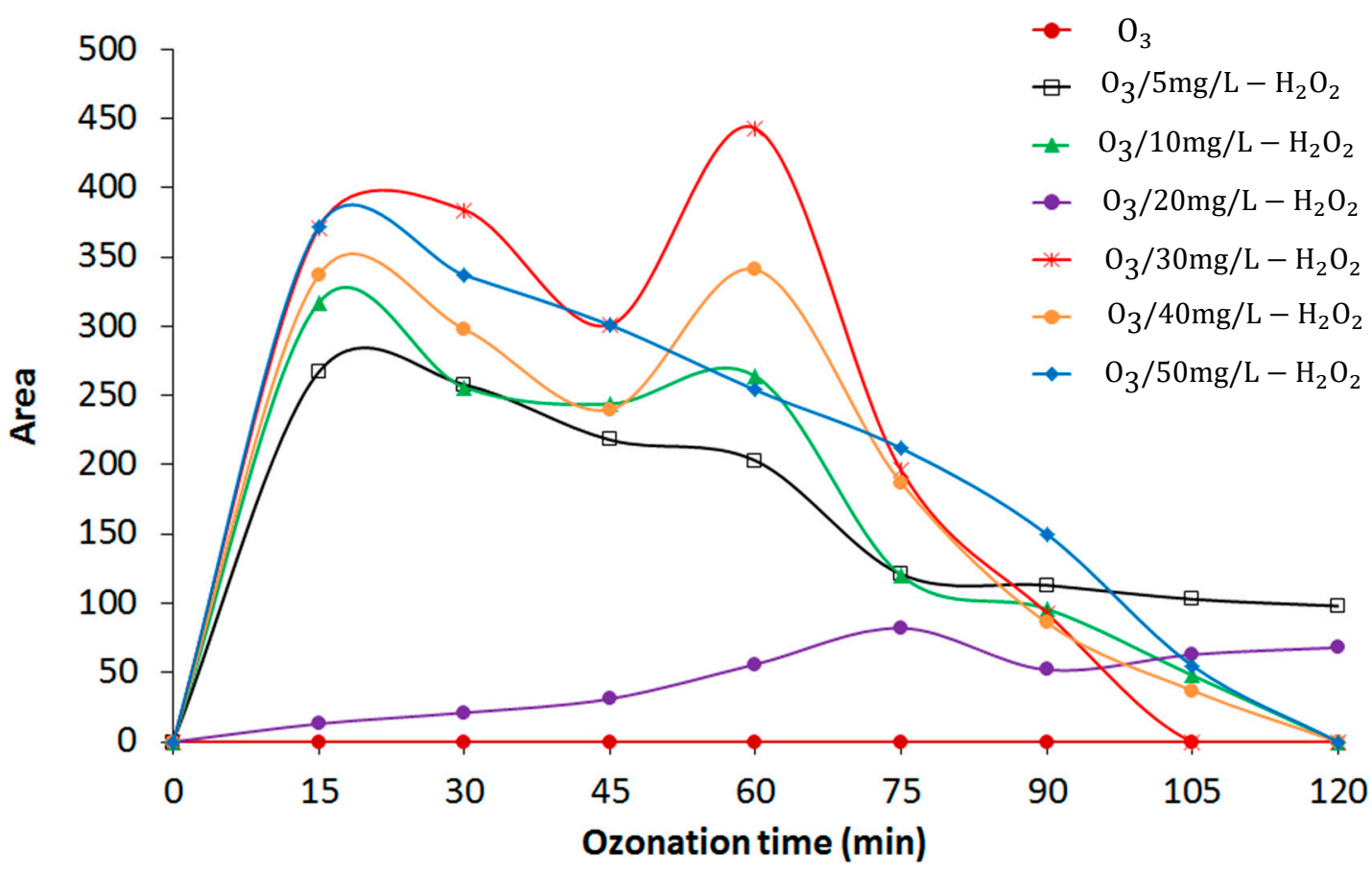

Figure 8. 4-Hydroxy phthalic acid as an intermediate diethyl phthalate (DEP) degradation product.

In addition, Figures 7 and 8 show that the areas of both phthalic acid and 4-hydroxy phthalic acid increased during the first $60 \mathrm{~min}$ of the $\mathrm{O}_{3} / \mathrm{H}_{2} \mathrm{O}_{2}$ treatment. As the treatment time increased, the intermediate products increased during the DEP degradation, reaching a maximum area, and then began to decrease as the experiment proceeded. Figure 7 shows that the area of phthalic acid decreased after 120 min while there was still residual phthalic acid in the leachate. 4-Hydroxy phthalic acid showed the same trend and there was a complete elimination of 4-hydroxy phthalic acid, except with 5 and $20 \mathrm{mg} / \mathrm{L} \mathrm{H}_{2} \mathrm{O}_{2}$ after $120 \mathrm{~min}$ (Figure 8). Table 3 shows the second-order reaction rate constants for the $\mathrm{O}_{3}$ and $\mathrm{OH}$ radical with DEP. 
Table 3. Second-order rate constants for the reaction of $\mathrm{O}_{3}$ and $\mathrm{OH}$ radicals with diethyl phthalate.

\begin{tabular}{cccc}
\hline Compound Name & $\mathbf{K}_{\mathrm{O}_{3}}\left(\mathbf{M}^{-\mathbf{1}} \mathbf{s}^{-\mathbf{1}}\right)$ & $\mathbf{K}_{\mathbf{O H}}\left(\mathbf{M}^{-1} \mathbf{s}^{-\mathbf{1}}\right)$ \\
\hline Diethyl phthalate & Structure & $0.06-0.1$ (Wen et al., 2011) & 2005) \\
\hline
\end{tabular}

\section{Conclusions}

The degradation of DEP by $\mathrm{O}_{3}$ alone and peroxone with varying concentrations of $\mathrm{H}_{2} \mathrm{O}_{2}$ was demonstrated. The simulated leachate had a high concentration of COD $(16,400 \mathrm{mg} / \mathrm{L})$ along with heavy metals, resulting in a complex matrix for the treatment process. DEP was not degraded by $\mathrm{O}_{3}$ alone [27], but it was degraded by the peroxone process due to the high rate removal by $\mathrm{OH}$ radicals $\left(3.9 \times 10^{9} \mathrm{M}^{-1} \mathrm{~s}^{-1}\right)$. The COD removal of DEP by $\mathrm{O}_{3}$ with $40 \mathrm{mg} / \mathrm{L} \mathrm{H}_{2} \mathrm{O}_{2}$ showed a $65 \%$ decrease in $120 \mathrm{~min}$ from the initial COD. Measurement of the in-gas and off-gas $\mathrm{O}_{3}$ dose during the treatment process revealed a rapid kinetic change in the initial treatment time that decreased toward the end of the treatment and influenced the oxidation process. The ozonation of leachate resulted in a minor change in $\mathrm{pH}$ due to the buffering effect of the bicarbonates. The $\mathrm{OH}$ radical exposure in a steady state was estimated using a radical probe compound, which confirmed the $\mathrm{OH}$ radical's reaction with the leachate and its effect on the contaminant degradation. Two intermediate products were detected using HPLC-MS during the DEP degradation: phthalic acid and 4-hydroxy phthalic acid. They were confirmed using available reference compounds and ESI (+) MS spectra. A trend analysis was performed to estimate their area and degradation during the treatment process.

Supplementary Materials: The following are available online at http://www.mdpi.com/1996-1944/12/24/4119/s1, Figure S1. Transferred ozone dosage; Figure S2. Influence of $\mathrm{O}_{3}$ and $\mathrm{O}_{3} / \mathrm{H}_{2} \mathrm{O}_{2}$ on $\mathrm{pH}$.

Author Contributions: S.M., H.M. and G.D., conceived the study and designed the experiments with the help of D.A.; G.D. performed the experiments; G.D. and A.K. analyzed the data with the help of I.G.; H.M. and D.A. contributed reagents/materials/analytical tools for the study; G.D. wrote the paper.

Funding: Our thanks to TATA-TAU program for financing Gokul Dayalan's travel to TAU. We would also like to thank V. Cohen-Yaniv and Roi Peretz for training G.D. on the ozone system.

Conflicts of Interest: The authors declare that there is no conflict of interest.

\section{References}

1. Kjeldsen, P.; Barlaz, M.A.; Rooker, A.P.; Baun, A.; Ledin, A.; Christensen, T.H. Present and long-term composition of MSW landfill leachate: A review. Crit. Rev. Environ. Sci. Technol. 2002, 32, 297-336. [CrossRef]

2. Calabrò, P.S.; Gentili, E.; Meoni, C.; Orsi, S.; Komilis, D. Effect of the recirculation of a reverse osmosis concentrate on leachate generation: A case study in an Italian landfill. Waste Manag. 2018, 76, 643-651. [CrossRef] [PubMed]

3. Wang, Z.; Shao, Y.; Gao, N.; Lu, X.; An, N. Degradation of diethyl phthalate (DEP) by UV/persulfate: An experiment and simulation study of contributions by hydroxyl and sulfate radicals. Chemosphere 2018, 193, 602-610. [CrossRef] [PubMed]

4. Asaithambi, P.; Sajjadi, B.; Abdul Aziz, A.R.; Daud, W.M.A.B.W. Ozone (O3) and sono (US) based advanced oxidation processes for the removal of color, COD and determination of electrical energy from landfill leachate. Sep. Purif. Technol. 2017, 172, 442-449. [CrossRef]

5. Xu, B.; Gao, N.Y.; Sun, X.F.; Xia, S.J.; Rui, M.; Simonnot, M.O.; Causserand, C.; Zhao, J.F. Photochemical degradation of diethyl phthalate with $\mathrm{UV} / \mathrm{H}_{2} \mathrm{O}_{2}$. J. Hazard. Mater. 2007, 139, 132-139. [CrossRef]

6. Bilardi, S.; Calabrò, P.S.; Greco, R.; Moraci, N. Selective removal of heavy metals from landfill leachate by reactive granular filters. Sci. Total Environ. 2018, 644, 335-341. [CrossRef] 
7. Papadopoulos, A.; Fatta, D.; Loizidou, M. Treatment of stabilized landfill leachate by physico-chemical and bio- oxidation processes. J. Environ. Sci. Heal. Part A Toxic/Hazard. Subst. Environ. Eng. 1998, 33, 651-670. [CrossRef]

8. Miklos, D.B.; Remy, C.; Jekel, M.; Linden, K.G.; Drewes, J.E.; Hübner, U. Evaluation of advanced oxidation processes for water and wastewater treatment - A critical review. Water Res. 2018, 139, 118-131. [CrossRef]

9. Deng, Y.; Zhao, R. Advanced Oxidation Processes (AOPs) in Wastewater Treatment. Curr. Pollut. Rep. 2015, 1, 167-176. [CrossRef]

10. Abu Amr, S.S.; Aziz, H.A.; Hossain, M.S.; Bashir, M.J.K. Simultaneous removal of COD and color from municipal landfill leachate using Ozone/Zinc sulphate oxidation process. Glob. Nest J. 2017, 19, 498-504.

11. Abu Amr, S.; Aziz, H.A.; Bashir, M.; Aziz, S.Q.; Alslaibi, T. Comparison and Optimization of ozone-Based Advanced Oxidation Processes in The Treatment of Stabilized Landfill Leachate. J. Eng. Res. Technol. 2015, 2, 122-130. [CrossRef]

12. Huang, W.B.; Chen, C.Y. Photocatalytic Degradation of Diethyl Phthalate (DEP) in water using $\mathrm{TiO}_{2}$. Water. Air. Soil Pollut. 2010, 207, 349-355. [CrossRef]

13. Jung, Y.J.; Oh, B.S.; Kim, K.S.; Koga, M.; Shinohara, R.; Kang, J.W. The degradation of diethyl phthalate (DEP) during ozonation: Oxidation by-products study. J. Water Health 2010, 8, 290-298. [CrossRef] [PubMed]

14. Halim, A.A.; Abidin, N.N.Z.; Awang, N.; Ithnin, A.; Othman, M.S.; Wahab, M.I. Ammonia and COD removal from synthetic leachate using rice husk composite adsorbent. J. Urban Environ. Eng. 2011, 5, 24-31. [CrossRef]

15. Mohan, S.; Gandhimathi, R. Removal of heavy metal ions from municipal solid waste leachate using coal fly ash as an adsorbent. J. Hazard. Mater. 2009, 169, 351-359. [CrossRef] [PubMed]

16. Peretz, R.; Gerchman, Y.; Mamane, H. Ozonation of tannic acid to model biomass pretreatment for bioethanol production. Bioresour. Technol. 2017, 241, 1060-1066. [CrossRef]

17. Rodger, B.; Laura, B. Standard Methods for the Examination of Water and Wastewater, 23rd ed.; American Public Health Association: Washington, DC, USA, 2017; pp. 1-101. ISBN 087553287X; 9780875532875.

18. Tizaoui, C.; Bouselmi, L.; Mansouri, L.; Ghrabi, A. Landfill leachate treatment with ozone and ozone/hydrogen peroxide systems. J. Hazard. Mater. 2007, 140, 316-324. [CrossRef]

19. Ozbelge, T.A.; Erol, F. Effects of $\mathrm{pH}$, initiator, scavenger, and surfactant on the ozonation mechanism of an Azo Dye (Acid Red-151) in a batch reactor. Chem. Eng. Commun. 2009, 196, 39-55. [CrossRef]

20. Zucker, I.; Lester, Y.; Avisar, D.; Hübner, U.; Jekel, M.; Weinberger, Y.; Mamane, H. Influence of wastewater particles on ozone degradation of trace organic contaminants. Environ. Sci. Technol. 2015, 49, 301-308. [CrossRef]

21. Otera, J. Transesterification. Chem. Rev. 1993, 93, 1449-1470. [CrossRef]

22. Elovitz, M.S.; von Gunten, U. Hydroxyl radical/ozone ratios during ozonation processes. I. the Rct concept. Ozone Sci. Eng. 1999, 21, 239-260. [CrossRef]

23. Pi, Y.; Schumacher, J.; Jekel, M. The Use of para-Chlorobenzoic Acid (pCBA) as an Ozone/Hydroxyl Radical Probe Compound. Ozone Sci. Eng. 2005, 27, 431-436. [CrossRef]

24. Wert, E.; Rosario-Ortiz, F.L.; Snyder, S.A. Using ultraviolet absorbance and color to assess pharmaceutical oxidation during ozonation of wastewater. Environ. Sci. Technol. 2009, 43, 4858-4863. [CrossRef] [PubMed]

25. Lakretz, A.; Mamane, H.; Cikurel, H.; Avisar, D.; Gelman, E.; Zucker, I. The Role of Soil Aquifer Treatment (SAT) for Effective Removal of Organic Matter, Trace Organic Compounds and Microorganisms from Secondary Effluents Pre-Treated by Ozone. Ozone Sci. Eng. 2017, 39, 385-394. [CrossRef]

26. Medellin-Castillo, N.A.; Ocampo-Pérez, R.; Leyva-Ramos, R.; Sanchez-Polo, M.; Rivera-Utrilla, J.; Méndez-Díaz, J.D. Removal of diethyl phthalate from water solution by adsorption, photo-oxidation, ozonation and advanced oxidation process $\left(\mathrm{UV} / \mathrm{H}_{2} \mathrm{O}_{2}, \mathrm{O}_{3} / \mathrm{H}_{2} \mathrm{O}_{2}\right.$ and $\mathrm{O}_{3}$ /activated carbon). Sci. Total Environ. 2013, 442, 26-35. [CrossRef] [PubMed]

27. Wen, G.; Ma, J.; Liu, Z.; Zhao, L. Ozonation kinetics for the degradation of phthalate esters in water and the reduction of toxicity in the process of $\mathrm{O}_{3} / \mathrm{H}_{2} \mathrm{O}_{2}$. J. Hazard. Mater. 2011, 195, 371-377. [CrossRef] [PubMed]

(C) 2019 by the authors. Licensee MDPI, Basel, Switzerland. This article is an open access article distributed under the terms and conditions of the Creative Commons Attribution (CC BY) license (http://creativecommons.org/licenses/by/4.0/). 